\title{
INSTITUTIONAL ACTORS AS INTERNATIONAL LAW-MAKERS IN BUSINESS AND HUMAN RIGHTS: THE UNITED NATIONS GUIDING PRINCIPLES ON BUSINESS AND HUMAN RIGHTS AND BEYOND
}

\begin{abstract}
Business and human rights is an interdisciplinary field, which advocates that both state and businesses are duty-holders of human rights obligations. The area of business and human rights aims to regulate and prevent negative impact of business operations at all levels of global supply chains. The approach of international law in this regard has so far been piecemeal. States have been traditionally a principal participant in the international community. Nonetheless, this article aims to test arguments submitted by Jovanovic in his 2019 book "The Nature of International Law" that institutional non-state actors are capable of creating international legal rules. Equipped with this knowledge, this article argues that the UN Human Rights Council has through adoption of the UN Guiding Principles on Business and Human Rights restated human rights obligations of states and indirectly of corporations in international law in order to protect the dignity of rights-holders in local and global environments.
\end{abstract}

Key words: philosophy of international law, institutional actors, business and human rights, human rights, state obligations, corporate obligations, UNGPs on Business and Human Rights.

\section{INTRODUCTION}

Companies have been in the last decades on only daily levels affecting the rights of the ordinary rights holders who are often left unprotected in the case of business-related human rights abuses. ${ }^{1}$ Business and human

* Professor of Constitutional and Human Rights Law, Faculty of Government and European Studies, New University, Ljubljana and Kranj, Slovenia; e-mail: jernej.letnar@ gmail.com

This piece was prepared within the framework of a research project co-financed by the Slovenian Research Agency: 'A Holistic Approach to Business and Human Rights' (no. JP-1790).

1 See, for example, Clapham, A., 2006, Human Rights Obligations of Non-State Actors, Oxford, Oxford University Press; Deva, S., 2012, Regulating Corporate Human Rights 
rights have been over the last decades a growing field attempting to promote awareness about human rights protection in business. ${ }^{2}$ States are often not able nor willing to bring justice to victims in the case of business-related human rights abuses. As such, rights-holders often do not have any recourse to enforce accountability for business-related human rights abuses. International law has in the past only indirectly regulated business and human rights. Domestic regulation of business and human rights have been, on one hand, progressing in the last decades, particularly within the ambit of the European Union and its Member States. On the other hand, states have so far not adopted international convention that would formally create obligations of state in business and human rights. One of the reasons for such lack of regulation is that the majority of states as primary participants in international law have been reluctant to regulate business and human rights at the international level. Nonetheless, recent years have illustrated a global effort to advance accountability for business-related human rights violations. ${ }^{3}$

Institutional non-state actors are a core part of non-state actors in international law. Nonetheless, a few international organisations have in the last decades in international law attempt to fill the gap in business and human rights. They have adopted guidelines that have thereafter been employed as a point of departure by majority if not all stakeholders in business and human rights ranging from states to businesses and civil society.

Violations: Humanizing Business, London, New York, Routledge; Deva, S., Bilchitz, D. (eds.), 2013, Human Rights Obligations of Business: Beyond the Corporate Responsibility to Respect, Cambridge, Cambridge University Press; Jägers, N., 2002, Corporate Human Rights Obligations: In Search of Accountability, Antwerp, Intersentia; Letnar Černič, J., 2010, Human Rights Law and Business, Groningen, Europa Law Publishing; Letnar Černič, J., Ho, T. van (eds.), 2015, Human Rights and Business: Direct Corporate Accountability for Human Rights, Wolf Publishing; Letnar Černič, J., 2020, Corporate Accountability under Socio-Economic Rights, (Transnational Law and Governance), Oxon, New York, Routledge.

2 Wettstein, F., The History of "Business and Human Rights" and Its Relationship with Corporate Social Responsibility, in: Deva. S., Birchall, D. (eds.), 2020, Research Handbook on Human Rights and Business, Cheltenham, Edward Elgar; Ramasastry, R., 2015, Corporate Social Responsibility Versus Business and Human Rights: Bridging the Gap Between Responsibility and Accountability, Journal of Human Rights, 14, p. 237.

3 Deva, S., Bilchitz, D. (eds.), 2013; Clapham, A., 2006; Ruggie, J. G., 2013, Just Business: Multinational Corporations and Human Rights, New York, W. W. Norton \& Co.; Deva, S., 2012; McCorquodale, R., Smit, L., Neely, S., Brooks, R., 2017, Human Rights Due Diligence in Law and Practice: Good Practices and Challenges for Business Enterprises, Business and Human Rights Journal, Vol. 2, Issue 2, pp. 195-224; Carrillo Santarelli, N., 2013, Necessity and Possibilities of the International Protection of Human Dignity from Non-State Violations, PhD Thesis, Universidad Autónoma de Madrid. 
Those soft law or quasi legal documents have through state and business practice attained binding status in the international community in various forms either through further legislative efforts or by judicial decisions of domestic and international courts. As such, Jovanović in his book on The Nature of International Law rightly pinpoints at one of the points of contention in international law, namely whether institutional non-state actors can participate in the international community and whether they can create international legal norms. Accordingly, he aptly asks "[...] whether some of their acts, which are not intended by founding treaties to be of a legal nature, do produce legal effects and whether those effects amount to law-making;"?4 As a result, Jovanović's pinpoints at one of the challenges in business and human rights. Commentators have often posed similar questions as to the nature and scope of the United Nations Guiding Principles on Business and Human Rights (hereinafter: UNGPs on Business and Human Rights or UNGPs) and OECD Guidelines for Multinational Enterprises. To this end, this article aims to examine the role of non-state actors as international law-makers in Business and Human Rights.

More specifically, this article therefore analyses the role of institutional non-state actors in international law-making in the field of business and human rights. It attempts to answer whether Jovanovićs approach to non-state actor is persuasive from the perspective of human rights protection in business operations. As such, it explores whether the UN Human Rights Council as one of the organs of the United Nations is competent to adopt binding international legal acts and norms. The UN Human Rights Council had in 2011 unanimously adopted United Nations Guiding Principles on Business and Human Rights (UNGPs on Business and Human Rights), which quickly turned into the main authoritative document in the global framework of business and human rights, often cited by domestic and regional human rights bodies and implemented in domestic systems. ${ }^{5}$ Its main proponent has often submitted that they were adopted consensually and they represent repetition of the already existing international legal obligations in international human rights. Accordingly, this article addresses challenges in placing human rights obligations on state and corporate actors from the point of view of the functions of institutional non-state actors in international law-making in the field of business and human rights.

4 Jovanović, M. A., 2019, The Nature of International Law, Cambridge, Cambridge University Press, p. 168.

5 Ruggie, J., 2008; Protect, Respect and Remedy: A Framework for Business and Human Rights: Report of the Special Representative of the Secretary-General on the Issue of Human Rights and Transnational Corporations and Other Business Enterprises, John Ruggie, A/HRC/8/5. 
This article includes four main sections. Section 2 studies the theoretical framework and underpinnings of business and human rights. Thereafter, section 3 analyses the legal nature and scope of UNGPs on Business and Human Rights. Finally, Section 4 explores whether UNGPs on Business and Human Rights could be considered as material and binding sources of international law? Equipped with this knowledge, this article argues that the UN Human Rights Council has through UNGPs on Business and Human Rights reinforced state human rights obligations in order to protect the dignity of rights-holders. ${ }^{6}$ All in all, it argues that UNGPs are a textbook example that at times institutional non-state actors are capable of producing binding law even though states formally did not intend to grant them legislative powers. It is a contribution to the debate that public or private institutional actors are capable of contributing to international-law making.

\section{The Theoretical Framework of Business and HUMAN Rights}

Ordinary people have been in the contemporary world exposed to the positive as well as negative impacts of business, which can also indirectly or directly violate human rights. Such abuses include violations of civil and political rights as well as economic and social rights, including the most severe violations such as participation in genocides, crimes against humanity and war crimes. Corporations themselves or, even more commonly, jointly with state actors interfere with individual's absolute rights, such as the right to life, a prohibition of torture, as well as rights such as rights to water, food and decent housing. The nature and extent of corporate violations varies according to geographical areas as well as to differences between corporations themselves. The bulk of violations are still committed in the Americas, Africa, Asia and Central and Eastern Europe. States have been traditionally the principal duty-bearer in human rights law. Nonetheless, also other actors may have obligations under human rights law in the business context. Business and human rights is an interdisciplinary area that states that states have primary obligations to protect individuals against business-related human rights abuses, but that also businesses have obligations to respect, protect and fulfil human rights in their business operations and throughout their global supply chains. ${ }^{7}$

6 See, for instance, Vasquez, C. M., 2005, Direct vs. Indirect Obligations of Corporations under International Law, Columbia Journal of Transnational Law, 43, p. 927.

7 See, for instance, Letnar Černič, J., 2020. 
It has spread over many layers and levels. Some regional and domestic legal systems, particularly in the Global North, have in the past years developed specialized sources of law in different sub-fields of business and human rights, mostly in the areas of non-financial reporting and mandatory due diligence. ${ }^{8}$ The European Union has particularly in the last decade introduced binding legislation in the field of business and human rights. ${ }^{9}$ Some domestic courts have in the past delivered judgements that established some forms of accountability for corporate human rights violations. ${ }^{10}$ The developments have been somewhat outstanding in international law. The access to remedy of rights-holders has been particularly lacking in business and human rights. Most domestic legal systems do not allow or only partially allow for the enforcement of corporate accountability for human rights violations in domestic systems as well as in third countries, which requires victims to resort to often ineffective and reluctant domestic courts of Asian, African and South American countries. In recent years, progress has been made only in Anglo-Saxon jurisdictions, especially in the English legal system. Victims can only in rare cases

8 Lorenzo, F. di, Levin-Nally, E., 2021, The "Conflict Minerals Regulation" or the "Regulation on Responsible Sourcing of Minerals": Evolving Purpose and Terminology, Business and Human Rights Journal Blog, 22 February, (https://www.cambridge.org/ core/blog/2021/02/22/the-conflict-minerals-regulation-or-the-regulation-on-responsible-sourcing-of-minerals-evolving-purpose-and-terminology/, 10. 11. 2021); Modern Slavery Act (UK, 2015); California Transparency in Supply Chains Act, CAL. CIV. CODE $\$ 1714.43$ (West, 2010); Modern Slavery Act 2018, Australia (No. 153, 2018). Loi 2017-399 du 27 Mars 2017 relative au devoir de vigilance des sociétés mères et des entreprises donneuses d'ordre, Official Gazette of the Republic of France, March 27, 2017; The Dutch Child Labour Due Diligence Law, Eerste Kamer, vergaderjaar 2016-2017, 34 506, A.

9 Directive 2014/95/EU of the European Parliament and of the Council of 22 October 2014 amending Directive 2013/34/EU as regards disclosure of non-financial and diversity information by certain large undertakings and groups. Text with EEA relevance; Regulation (EU) 2017/821 of the European Parliament and of the Council of 17 May 2017 laying down supply chain due diligence obligations for Union importers of tin, tantalum and tungsten, their ores, and gold originating from conflict-affected and high-risk areas, OJ L 130, 19. 5. 2017, p. 1-20.

10 Vedanta Resources PLC and another v. Lungowe and others; [2019] UKSC 20. Judgment,(https://www.supremecourt.uk/cases/docs/uksc-2017-0185-judgment.pdf, 10. 11. 2021). UK Supreme Court, 10 April 2019, at para. 61. See generally Yilmaz-Vastardis, A., Leader, S., 2017, Improving Paths to Business Accountability for Human Rights Abuses in the Global Supply Chains, Essex Business and Human Rights Project, (https:// wwwl.essex.ac.uk/ebhr/documents/Improving-Paths-to-Accountability-for-Human\%20Rights-Abuses-in-the-Global-Supply-chains-A-Legal-Guide.pdf, 10. 11. 2021); Connelly v. R.T.Z. Corporation, [1998] A.C. 854 at 868-69; Connelly v. R.T.Z. Corp. Plc., [1998] A.C. 854 (House of Lords) (citing Sim v. Robinow, 1892 Sess. Cas. (R.) 668 and Spiliada Maritime Corp. v. Cansulex Ltd., [1987] A.C. 460, 474. 
enforce corporate accountability within the jurisdictions of the countries where they are registered. The right to effective remedy is one of the basic tenets of human rights justice. The UN High Commissioner for Human Rights noted some years ago that "[...] accountability and remedy in such cases is often elusive. Although causing or contributing to severe human rights abuses would amount to a crime in many jurisdictions, business enterprises are seldom the subject of law enforcement and criminal sanctions." ${ }^{11}$ Challenges "[...] include fragmented, poorly designed or incomplete legal regimes; lack of legal development; lack of awareness of the scope and operation of regimes; structural complexities within business enterprises; problems in gaining access to sufficient funding for private law claims; and a lack of enforcement." ${ }^{2}$ As a result, civil society organisations have been pressuring the governments to pay attention to the plight of individuals suffering due to the negative impact of business activities.

Some international organisations have developed quasi-legal business and human rights documents in the field of human rights, investment and labour rights. The global civil society has therefore over the past two decades advocated for the adoption of the UN Treaty on Business and Human Rights. The UNGPs have not fully satisfied global civil society, who have argued that binding convention at international level is indispensable for the advancement of business and human rights. As a result, the United Nations Human Rights Council on 26 June 2014 adopted resolution A/HRC/ $\mathrm{RES} / 26 / 9$ "to establish an open-ended intergovernmental working group on transnational corporations and other business enterprises with respect to human rights, whose mandate shall be to elaborate an international legally binding instrument to regulate, in international human rights law, the activities of transnational corporations and other business enterprises." ${ }^{3}$ The Treaty Alliance, a group of international NGOs noted that the potential international convention is to ensure that human rights have a precedence of the interest and rights of corporations in order to provide rightsholders with access to supervisory mechanisms, which would be able to hear their claims. ${ }^{14}$ Victims have often encountered insurmountable

11 United Nations High Commissioner for Human Rights, Report on "Improving accountability and access to remedy for victims of business-related human rights abuse", United Nations General Assembly, A/HRC/32/19, (10 May 2016), para. 2.

12 Ibid., para. 4.

13 UN Human Rights Council Resolution A/HRC/RES/26/9, adopted 14 July 2014, (https://undocs.org/A/HRC/RES/26/9, 20. 11. 2021), p. 2.

14 Treaty Alliance, We call on states to participate actively in upcoming negotiations of the international treaty to ensure protection of human rights from the activities of transnational corporations and other business enterprises, 29 May 2015, (https:// www.business-humanrights.org/en/treaty-alliance-joint-statement-calls-for-signa- 
obstacles to enforce accountability for alleged corporate human rights violations. As such, the Treaty would grant rights-holders with the access to fair, impartial and independent judicial, quasi-judicial or non-judicial proceedings where their allegations about business-related human rights abuses would be heard and addressed. The Elements for the Draft Legally Binding Instrument in 2017 envisaged that the potential UN Treaty on Business and human rights would create binding corporate obligations to comply with human rights throughout their global chains that are recognized by the international community in the form of the already existing international human rights treaties. ${ }^{15}$ To this end, it noted that corporations are to identify potential actual human rights challenges at all levels of their business operations, including in their relationship with suppliers and other business partners. ${ }^{16}$ As such, corporations would be also asked to provide access to justice and reparations to victims of business-related human rights abuses. ${ }^{17}$ As a result, corporations are to take preventive steps and adopt preventive measures to avoid human rights violations and comply with domestic and international human rights. They are to develop effective, fair and independent international supervisory that would monitor on daily levels the business compliance with human rights. ${ }^{18}$ The Intergovernmental Working Group has so far held seven rounds of negotiations, however there is still no final agreement on the wording of the draft text. The countries of the Global North appear particularly reluctant to support the idea of binding obligations of states to protect individuals against corporate human rights violations. On the other hand, the Member States of the European Union and other countries of the Global North appear to be open to supporting the potential

tures-in-favour-of-proposed-binding-treaty-to-enhance-corporate-legal-accountability-for-rights-abuses, 10. 11. 2021). See for instance, Lopes, R., Kwesiga, A., 2018, What the Zero Draft and Protocol Lack: Meaningful Access to Justice - A Global South Perspective, Business and Human Rights Resource Centre, 8 October, (https://www.business-humanrights.org/en/blog/what-the-zero-draft-and-protocol-lack-meaningful-access-tojustice-a-global-south-perspective/, 20. 11. 2021); Lappin, K., Pedersen, H., Khan, T., 2016, Influence of corporations in treaty process would undermine affected communities' interests, Business \& Human Rights Resource Centre, March 28, (http://business-humanrights.org/en/influence-of-corporations-in-treaty-process-would-undermine-affected-communities\%E2\%80\%99-interests, 20. 11. 2021). See also Jägers, N., 2011, UN Guiding Principles on Business and Human Rights: Making Headway Towards Real Corporate Accountability?, Netherlands Quarterly of Human Rights, 29, p. 159.

15 Elements for the Draft Legally Binding Instrument on Transnational Corporations and Other Business Enterprises with Respect to Human Rights, Chairmanship of the OEIGWG established by HRC Res. A/HRC/RES/26/9, 29 September 2017, para. 3.3.

16 Ibid.

17 Ibid.

18 Ibid. 
draft of the Business and Human Rights Treaty that would be based on the UNGPs on Business and Human Rights.

\section{The Legal Nature and Scope of UNGPs on Business and Human Rights}

John Ruggie conceived UNGPs as a tool that would assist businesses in identifying and responding to human rights risks in their operations. He refrained from developing other legal documents that would include complex legal languages as most businesses would not be able to grasp and internalize in their business operations. ${ }^{19}$ UNGPs were drafted as a practical document ready to be employed by business managers in the already existing risk management procedures. ${ }^{20}$ They are to assist businesses to avoid negative human rights impact throughout the global supply chains of their business operations. ${ }^{21}$ The idea for such business-oriented activities derived from John Ruggie's previous work with the voluntary Global Compact initiative. ${ }^{22}$ As such, many traits of his previous work have been translated also in the consultations and drafting of the UNGPs. As such, the UNGPs were not primarily designed as a human rights document but as a tool box to be employed by businesses. Catá Backer argues that Ruggie's "framework seeks inter-systemic harmonization that is socially sustainable, and thus stable. The framework recognizes and operationalizes emerging governance regimes by combining the traditional focus on the legal systems of and between states with the social systems of non-state actors and the governance effects of policy[...]" ${ }^{23}$ Such an approach has been criticised by human rights scholars, who have expressed concern that the UNGPs do not provide added value. De Schutter noted that "[...] substantive choices may hide behind terminological matters. For instance, mentioning 'impacts' rather than 'violations' reveals a shift from a legal to a managerial conception of the responsibility of business". ${ }^{24}$ Nonetheless,

19 Ruggie, J. G., 2014, Global Governance and "New Governance Theory”: Lessons from Business and Human Rights, Global Governance, Vol. 20, Issue 1, pp. 5, 14.

20 Ibid.

21 Ibid.

22 Ibid.

23 Cata Backer, L., 2012, From Institutional Misalignments to Socially Sustainable Governance: The Guiding Principles for the Implementation of the United Nations Protect, Respect and Remedy and the Construction of Inter-Systemic Global Governance, Pacific McGeorge Global Business \& Development Law Journal, Vol. 25, Issue 1, pp. 69-172.

24 Schutter de, O., Foreword: Beyond the Guiding Principles, in: Deva, S., Bilchitz, D. (eds.), 2013, pp. xv-xxii. 
the process of drafting of the UNGPs has been to some extent open and included stakeholders from different arenas. Deva recognizes that the drafter of the UNGPs attempted to obtain the view of various stakeholders in different regions, professions and industries in order to increase the credibility and acceptance of the principles. ${ }^{25}$ Similarly, Hamm notes that Ruggie attempted to include all stakeholders in the consultation during the drafting process of the UNGPs. ${ }^{26} \mathrm{He}$ particularly aimed to pay attention to the views of the business community, which was previously excluded from, for instance, drafting of the UN Norms. ${ }^{27}$ Such an approach has been reflected in the Pillar 2 of the UNGPs, where corporate responsibility for human rights is defined as social and as legal norm. ${ }^{28}$ Corporations advocated for voluntary, not binding approaches in business and human rights. Nonetheless, it seems that John Ruggie has not paid appropriate attention to civil society and victims' organisations who have throughout the process argued for a greater place of rights-holders in the UNGPs. The author of the UNGPs on Business and Human Rights wished to move beyond the UN Norms on Business and Human Rights ${ }^{29}$, which employed a rights-based approach to business and human rights. However, states and business communities have not expressed full support for their adoption and opted to support the new project.

As far their contents go, the UNGPs on Business and Human Rights include foundational and operational principles. It created three sets of obligations of stakeholders in business and human rights, namely: "States' existing obligations to respect, protect and fulfil human rights and fundamental freedoms; the role of business enterprises as specialized organs of society performing specialized functions, required to comply with all applicable laws and to respect human rights; the need for rights and

25 Deva, S., Treating Human Rights Lightly: A Critique of the Consensus Rhetoric and the Language Employed by the Guiding Principles, in: Deva, S., Bilchitz, D. (eds.), 2013, pp. 78-104.

26 Hamm, B., 2021, The Struggle for Legitimacy in Business and Human Rights Regulation - A Consideration of the Processes Leading to the UN Guiding Principles and an International Treaty, Human Rights Review, (https://doi.org/10.1007/s12142-02000612-y), p. 19.

27 Ibid.

28 Ibid.

29 UN Norms on the Responsibilities of Transnational Corporations and Other Business Enterprises with Regard to Human Rights, UN doc. E/CN.4/Sub.2/2003/12/ Rev. 2 (2003). See also Kinley, D., Nolan, J., Zerial, N., 2007, The Politics of Corporate Social Responsibility: Reflections on the United Nations Human Rights Norms for Corporations, Company and Securities Law Journal, Vol. 25, Issue 1, pp. 30-42; Weissbrodt, D., Kruger, M., 2003, Norms on the Responsibilities of Transnational Corporations and Other Business Enterprises with Regard to Human Rights, American Journal of International Law, 97, p. 901. 
obligations to be matched to appropriate and effective remedies when breached." 30 The UNGPs first establishes obligations of states to ensure that individuals are protected for business-related human rights abuses. Principle 1 provides that states are the primary responsible to protect individuals against corporate human rights violations in their territory. ${ }^{31}$ They do not, however, recognize that states have human rights obligations beyond their borders to regulate businesses and not violate human rights of individuals, for instance, in the Global South. The UNGPs ask states in Principle to provide businesses registered in their domestic legal system with clear rules that they are to observe human rights. ${ }^{32}$ States therefore have obligations to make sure that businesses in their territory observe human rights. To this end, they are to adopt normative but also policy mechanisms to control businesses in their territory. Their obligations are broader and more extensive in relation to the state-owned companies, where states are asked to lead by example. States have negative and positive obligations to observe human rights in their business environments.

Human rights obligations of businesses derive from Pillar 2 of the UNGPs on Business and Human Rights. UNGPs provide in Principle 11 that "Business enterprises should respect human rights". ${ }^{33}$ They explain corporate obligations in terms of negative nature obligations. More specifically, they require that corporations do infringe human rights of individuals and groups. Negative obligations are obligations of result. As for the content of such obligations, the UNGPs explain in principle 12 that "the responsibility of business enterprises to respect human rights refers to internationally recognized human rights - understood, at a minimum, as those expressed in the International Bill of Human Rights and the principles concerning fundamental rights set out in the International Labour Organization's Declaration on Fundamental Principles and Rights at Work". ${ }^{34}$ The UNGPs constructed corporate obligations to observe human rights in terms of social expectations, not legal norms. Nonetheless, the UNGPs have not limited themselves only to the negative obligations of businesses. ${ }^{35}$ They also provide for positive obligations, which derive from

30 UNGPs on Business and Human Rights, General Principles, p. 1.

31 UNGPs on Business and Human Rights, Principle 1.

32 Ibid., Principle 2.

33 Ibid., Principle 11.

34 Ibid., Principle 12.

35 Kinley, D., Tadaki, J., 2004, From Talk to Walk: The Emergence of Human Rights Responsibilities for Corporations at International Law, Virginia Journal of International Law, 44, p. 931; Ramio Marles, C., Alsina Burgues, V., 2016, The Role of the Ombudsman in Protecting the Rights of Consumers of Services of General Interest Provided by Private Companies, US-China Law Review, 13, p. 181; McCorquodale, R. 
Principle 15 and further UNGPs principles. They stipulate in Principle 15 that businesses are to take active measures to prevent business-related human rights violations. In this way, they ask corporations to introduce internal human rights policies, human rights due procedures and provide rights holders with access to non-judicial, quasi-judicial and judicial procedures. ${ }^{36}$ Those obligations are arguably the essential part of the UNGPs as they impose due diligence and remedial obligations on businesses. They are positive in nature and impose an obligation of conduct on businesses. Of particular importance is Principle 17 which sets out requirements of human rights due diligence that businesses are asked to follow when they identify risks and potential and actual negative consequences of their business operations. ${ }^{37}$ They are obliged to adapt their business operations on the basis of the findings in order to eliminate future risks. ${ }^{38}$ As a result, many businesses have, upon the adoption of the UNGPs, introduced human rights due diligence in their internal processes. Several states, mostly in the global North have introduced mandatory due diligence laws, which require corporations to not only to report on non-financial indicators, but also to include due diligence processes in their business operations.

As such, the UNGPs's due diligence concept has also provided incentive for adoption of due diligence legislation in several domestic systems, which provide for mandatory non-financial reporting and mandatory due diligence. ${ }^{39}$ As for access to remedy, the UNGPs provide in the principle 25, the main principle of its Pillar III, that "As part of their duty to protect against business-related human rights abuse, States must take appropriate steps to ensure, through judicial, administrative, legislative or other appropriate means, that when such abuses occur within their territory and/or jurisdiction those affected have access to effective remedy." 40 The obligations to provide the access to remedy therefore rest with states, which traditionally through the judicial branch of government enforce different forms of responsibility for human rights abuses. For those reasons, what is required is a reform of the domestic and international legal orders concerning corporate

et al., 2017, Human Rights Due Diligence in Law and Practice: Good Practices and Challenges for Business Enterprises, Business and Human Rights Journal, Vol. 2, Issue 2, pp. 195-224; Michalowski, S., 2012, No Complicity Liability for Funding Gross Human Rights Violations, Berkeley Journal of International Law, 30, p. 451.

36 UNGPs on Business and Human Rights, Principle 15.

37 Ibid., Principle 17.

38 Ibid.

39 Nolan, J., 2017, Business and human rights: The challenge of putting principles into practice and regulating global supply chains, Alternative Law Journal, Vol. 42, Issue 1, pp. $42-46$.

40 Ruggie, J., 2008, Principle 25. 
responsibility and accountability for human rights. The UNGPs on Business and Human Rights therefore established clear obligations that states and corporations are obligated to follow in the area of human rights.

\section{UNGPs on Business and Human Rights as Material and Binding Source OF INTERNATIONAL LAW?}

Commentators have over the last decade heavily debated the legal nature, value and impacts of the UNGPs on Business and Human Rights. ${ }^{41}$ Undoubtedly, the UNGPs on Business and Human Rights have not been adopted as an international human rights treaty. On the contrary, they were adopted by the UN Human Rights Council, which although being a principal human rights organ of the $\mathrm{UN}$, is formally structured under the UN General Assembly. As such, they do not formally create direct human rights obligations as any other guidelines and resolutions. ${ }^{42}$ The legal nature of the UNGPs on Business and Human Rights is therefore formally in the realm of soft law. ${ }^{43}$ It is of non-legal or quasi-judicial nature. Lagoutte argues that "Guiding principles and guidelines adopted by the UN General Assembly or the Committee of Ministers of the Council of Europe are negotiated and debated among the member states of the organization. Hence UN guiding principles such as the UNGPs only represent an

41 Ruggie, J. G., 2013, Just Business: Multinational Corporations and Human Rights, New York, W. W. Norton \& Co.; Ruggie, J. G., 2004, Business and Human Rights: The Evolving Agenda, American Journal of International Law, 101, p. 819; Martin Amerson, J., 2012, The End of the Beginning? A Comprehensive Look at the Business and Human Rights Agenda from a Bystander Perspective, Fordham Journal of Corporate and Finance Law, 17, p. 871; Aaronson, S. A., Higham I., 2013, "Re-righting Business": John Ruggie and the Struggle to Develop International Human Rights Standards for Transnational Firms, Human Rights Quarterly, 35, p. 333; Jägers, N., 2011, UN Guiding Principles on Business and Human Rights: Making Headway Towards Real Corporate Accountability? Netherlands Quarterly of Human Rights, 29, p. 159; Felice D. de, Graf, A., 2015, The Potential of National Action Plans to Implement Human Rights Norms: An Early Assessment with Respect to the UN Guiding Principles on Business and Human Rights, Journal of Human Rights Practice, 7, p. 40.

42 Chinkin, C., 2000, Normative Development in the International Legal System, in: Shelton, D. (ed.), Commitment and Compliance: The Role of Non-binding Norms in the International Legal System, Oxford, Oxford University Press, pp. 21-42.

43 See, for example, Catá Backer, L., 2015, Moving Forward the UN Guiding Principles for Business and Human Rights: Between Enterprise Social Norm, State Domestic Legal Orders, and the Treaty Law That Might Bind Them All, Fordham International Law Journal, 38, pp. 457-542. 
initial crystallization of the states' goodwill." ${ }^{44}$ Nonetheless, such views are not shared by some of the leading scholars in business and human rights. Deva argues that one should not question the legal power of the UNGPs as a tool to advance the position of rights-holders. ${ }^{45}$ However, the UNGPs have in the international arena restated obligations to states and corporations in business and human rights. To this end, they have strengthened the protection of rights-holders in business and human rights. As a result, what is the nature of the UNGPs from the viewpoint of distinction between formal and material sources of international law?

Commentators have argued that formal sources include those that fall within one defined category of sources of international law. ${ }^{46}$ On the other hand, material sources of international law refer to the practice of participants in international law. ${ }^{47}$ From a point of view of formal sources of international law, the UNGPs do not formally create binding obligations. Nonetheless, its principal author, the late professor John Ruggie, has always maintained that the UNGPs on Business and Human Rights are a reflection of the existing international human rights law. Even though he recognized that the UNGPs are soft law documents, he advocated that their power arises from the practice of states. Soft law documents are generally not considered as formal sources of international law. ${ }^{48}$ Nonetheless, Dupuy concedes that legal norms included in the soft law could eventually create binding obligations depending on the context and state practice. ${ }^{49}$ Accordingly, Ruggie, Rees and David argued that "Guiding

44 Lagoutte, S., 2016, The UN Guiding Principles on Business and Human Rights: A Confusing "Smart Mix" of Soft and Hard International Human Rights Law, in: Lagoutte, S., Gammeltoft-Hansen, T., Cerone, J. (eds.), Tracing the Roles of Soft Law in Human Rights, Oxford, Oxford University Press, pp. 235-253, 243.

45 Deva, S., 2021, The UN Guiding Principles' Orbit and Other Regulatory Regimes in the Business and Human Rights Universe: Managing the Interface, Business and Human Rights Journal, Vol. 6, Issue 2, pp. 336-351, 350.

46 Besson, S., Aspremont, J. d', The Sources of International Law: An Introduction, in: Besson, S., Aspremont, J. d' (eds.), 2014, The Oxford Handbook of the Sources of International Law, Oxford, Oxford University Press, pp. 25-26.

47 Ibid., p. 6. See also Aspremont, J. d', 2011, Formalism and the Sources of International Law. A Theory of the Ascertainment of Legal Rules, Oxford: Oxford University Press.

48 See, for instance, Pauwelyn, J., Wessel, R. A., Wouters, J. (eds.), 2012, Informal International Lawmaking, Oxford, Oxford University Press; Cf. Maastricht principles on extraterritorial obligations of states in the area of economic, social and cultural rights, 21 October 2011; Schutter, O. de et al., 2012, Commentary to the Maastricht principles on extraterritorial obligations of states in the area of economic, social and cultural rights, Human Rights Quarterly, Vol. 34, Issue 4, pp. 1084-1169.

49 Dupuy, P-M., 1991, Soft Law and the International Law of the Environment, Michigan Journal of International Law, 12, p. 431. 
principles authoritatively define a universe of discourse and establish its basic parameters and perimeters. Their constitutive elements achieve uptake to the extent that they have intrinsic persuasive power, inspire or justify prescribed conduct, engender shared expectations of ends and means, as well as other such normative and epistemic factors." 50 They appear to claim that UNGPs are considered a material source of international law.

Other scholars have emphasized that they have been adopted unanimously, which reflects state commitment and recognition of UNGPs as material sources of international regulation of business and human rights. ${ }^{51}$ Nonetheless, such conclusions have not been followed in practice, where less than thirty states have adopted National Action Plans on Business and Human Rights. In spite of the low number of adoption of National Action Plans, the impact and legitimacy of the UNGPs cannot be underestimated. It is submitted that the adoption of the UNGPs on Business and Human Rights has three-fold added value for creating international legal obligations in the field of business and human rights, perhaps not in the formal understanding of the sources of public international law, but surely from the perspective of material sources of international law.

First, the content of the majority of the principles included UNGPs on Business and Human Rights have been reflections of the customary and treaty international human rights obligations that states carry in international human rights law concerning supervision of private actors. Undoubtedly, the UNGPs illustrate the growing consensus among domestic systems that states and corporations are obliged to respect human rights. It has been generally accepted by several international and regional human rights bodies that states have positive obligations of binding nature to protect human rights of private actors in their horizontal relationships. ${ }^{52}$ State obligations to strive to prevent human rights violation in the horizontal relationship are widely recognized, for instance, in the European regional system of human rights protection. ${ }^{53}$ Moreover, domestic and regional legal systems have increasingly recognized that corporations have human rights obligations and are to ensure that in their business activities

50 Ruggie, J., Rees, C., Davis, R., 2021, Years After: From UN Guiding Principles to Multi-Fiduciary Obligations, Business and Human Rights Journal, Vol. 6, Issue 2, pp. 179-197.

51 Addo, M., 2014, The Reality of the United Nations Guiding Principles on Business and Human Rights, Human Rights Law Review, Vol. 14, pp. 133-47.

52 Letnar Černič, J., 2020.

53 See, for instance, Lavrysen, L., 2017, Human Rights in a Positive State, Rethinking the Relationship between Positive and Negative Obligations under the European Convention on Human Rights, Cambridge, Intersentia. 
do not infringe human rights. The UN Human Rights Council, as an institutional non-state stakeholder, has by adopting the UNGPs participated in international law making through restating existing state human rights obligations. They have adopted a perhaps formally declarative legal document of soft law legal nature, which nonetheless includes binding international legal obligations that derive from other formally binding sources of international law. As a result, the substance of the UNGPs could be considered as part of material sources of international law.

Second, the domestic and regional courts have over the past decade judicialized the UNGPs. Courts have included them in their judgements and decisions as an authoritative source of international law thereby recognizing that the nature of UNGPs stretches beyond soft law. ${ }^{54}$ Courts have employed the tripartite framework of UNGPs to deliver reasoned judgement in business and human rights. Further, the UN Human Rights bodies have also not only referred to, but also relied on the normative power of the UN human rights bodies. ${ }^{55}$ Additionally, 26 states have so far adopted National Action Plans and translated the UNGPs in domestic legal systems, even though much ground remains to be covered for them to be fully translated in domestic fora. ${ }^{56}$ National human rights institutions have started to include UNGPs into their promotional and restorative human rights activities. ${ }^{57}$ Several states have adopted national legislation in

54 García Muñoz, S., 2019, Special Rapporteur on Economic, Social, Cultural and Environmental Rights, Business and Human Rights: Inter-American Standards, IDH, (http:// www.oas.org/en/iachr/reports/pdfs/Business_Human_Rights_Inte_American_Standards.pdf); Márquez Carrasco, C., Vivas Tesón, I., (eds.), 2017, La implementación de los Principios Rectores de las Naciones Unidas sobre empresas y los derechos humanos por la Unión Europea y sus Estados miembros, Aranzadi Thomson Reuters: Ministerio de Economía, Industria y Competitividad, Madrid, 2017. See also Sanders, A., The Impact of the "Ruggie Framework" and the United Nations Guiding Principles on Business and Human Rights on Transnational Human Rights Litigation, in: Martin, J., Bravo, K., (eds.), 2016, The Business and Human Rights Landscape: Moving Forward, Looking Back, Cambridge, Cambridge University Press, pp. 288-315.

55 See, for instance, United Nations Committee on Economic, Social and Cultural Rights, General Comment No. 24 on State obligations under the International Covenant on Economic, Social and Cultural Rights in the context of business activities, E/C.12/GC/24 (10 August 2017).

56 UN Working Group on the issue of human rights and transnational corporations and other business enterprises, State National Action Plans, (https://www.ohchr.org/EN/ Issues/Business/Pages/NationalActionPlans.aspx, 20. 11. 2021); Bauer, J., 2016, What Good is a NAP for Developing Countries? A Preliminary Assessment of Achievements and Prospects for National Action Plans on Business and Human Rights in the Global South, SSRN, (https://ssrn.com/abstract=3221052).

57 Haász, V., 2013, The Role of National Human Rights Institutions in the Implementation of the UN Guiding Principles, Human Rights Review, 14, pp. 165-187. 
business and human rights inspired by the UNGPs. ${ }^{58}$ As a result, the evidence suggests that UNGPs have been at least partially domesticated in the national legal systems. ${ }^{59}$ In this way, domestic systems provide evidence that the UNGPs have at least to some extent converted into (material) sources of international law. ${ }^{60}$

Third, the normative power of the UNGPs has propelled the calls for binding normative documents at international level. The main proposal for the potential UN Treaty has been built on complementarity with the UNGPs. ${ }^{61}$ It is based on binding state obligations to respect, protect and fulfil human rights against potential corporate human rights violations. If adopted, States would be able to require businesses to conduct human rights due diligence through their supply chains. Equally important, the potential UN Treaty would also establish a legal basis for criminal, civil and administrative liability of corporations in their domestic systems. As a result, it would provide rights-holders with the access to remedy in business-related human rights abuses through domestic different modes of legal liability and provide them with reparations. On the contrary, another, competing, proposal has advocated for the direct translation of UNGPs in the UN Treaty, which would make the UNGPs formally binding in public international law. ${ }^{62}$ Such a proposal would formally recognize the binding nature of the UNGPs and make them already formally binding. The UNGPs have, as a result, provided a springboard for further development of the regulation in the field, which has been so under-regulated in the past.

58 Sorgfaltsprüfung bezüglich Menschenrechte und Umwelt im Zusammenhang mit Auslandaktivitäten von Unternehmen: Kein Schweizer Alleingang in der Gesetzgebung (2019), Bern, (https://static.woz.ch/sites/woz.ch/files/text/download/lobbyschreiben von_8august2019.pdf, 20. 7. 2021); Loi 2017-399 du 27 mars 2017 relative au devoir de vigilance des sociétés mères et des entreprises donneuses d'ordre, JORF n0074 du 28 mars 2017, Gesetz über die unternehmerischen Sorgfaltspflichten in Lieferketten. Bundesgesetzblatt Jahrgang 2021, Nr. 46, 22. 7. 2021, 2959, (https://www.bgbl.de/xaver/bgbl/start.xav?startbk=Bundesanzeiger_BGBl\#__bgbl_\%2F\%2F*\%5B\%40attr_id\%3D\%27bgbl121s2959.pdf\%27\%5D_1627115664209, 15. 11. 2021).

59 Wettstein, F., 2021, Betting on the Wrong (Trojan) Horse: CSR and the Implementation of the UN Guiding Principles on Business and Human Rights, Business and Human Rights Journal, Vol. 6, Issue 2, pp. 312-325.

60 Choudhury, B., Hardening Soft Law Initiatives in Business and Human Rights, in: Plessis, J. J. du, Keong Low, C. (eds.), 2017, Corporate Governance Codes for the $21^{\text {st }}$ Century, Cham, Switzerland, Springer.

61 Blackwell, S., Vander Meulen, N., 2016, Two Roads Converged: The Mutual Complementarity of a Binding Business and Human Rights Treaty and National Action Plans on Business and Human Rights, Notre Dame Journal of International and Comparative Law, 6, p. 51.

62 O'Brien, C., 2020, Transcending the Binary: Linking Hard and Soft Law Through a UNGPS-Based Framework Convention, AJIL Unbound, 114, pp. 186-191. 
All in all, institutional non-state participants have a role to play as international law-makers in the field of business and human rights. As such, one can answer the initial question posed by Jovanović in his book. It submitted that one can confirm that the UNGPs, even though they were not meant to be of binding nature, under certain conditions produce binding legal obligations of corporations and states. ${ }^{63}$ UNGPs are a material source of international law. Those conditions include the content of soft law international legal documents. If institutional actors adopt a soft law document that includes already existing international legal obligations, its nature will be at least materially binding. The UNGPs can already at this moment produce binding obligations as their content to the large extent derives from the already existing obligations that states and corporations have in customary and treaty international law. As such, one can persuasively argue that the UN Human Rights Council and its Member states have by adopting UNGPs participated in international law making as self-standing participants. The UNGPs on Business and Human Rights are now an authoritative and legitimate legal source of binding obligations of states and corporations in businesses and human rights. To this end, one should not turn a blind eye to the capacity and ability of institutional non-state actors in international law. As a result, the UNGPs are textbook examples that institutional non-state actors are capable of producing binding law even though states did not intend to grant them with legislative powers.

\section{Conclusion}

This article studied institutional actors as international law-makers in drafting and adopting binding documents in the area of human rights protection in business. More specifically, it analysed whether the UN Human Rights Council as a subsidiary organ of the United Nations has through the adoption and impact of United Guiding principles on Business and Human Rights been participating in the creation of international relations even though traditional sources of international relations would not allow for such participation. To be clear, international institutional actors traditionally do not belong among those stakeholders in international law that are free to create and amend rules of international law. To the contrary, the creation of the rules in public international law traditionally rests on the willingness and ability of states as primary participants or subjects of international law. Nonetheless, the last decades has shown that scholars of international law should not dismiss the persuasive ability and normative capacity of participants in international law beyond state to develop binding rules of international law. Such interpretation concurs with Jovanovićs

63 Jovanović, M. A., 2019, p. 168. 
observations as to the ability of institutional non-state actors to have equal legal standing in international law-making, but it also substitutes the traditional function of the state in business and human rights, which has been often captured by the private actors. ${ }^{64}$ In spite of states still being the primary participants in international law, the credibility and legitimacy does not only hinge on their ability and willingness to accept new legal rules, but also on the content of soft law documents such as UNGPs. Such arguments are perhaps even more persuasive in a legal system such as international law, which does not have a very clear hierarchy of legal norms nor there exists a permanent judicial institution with compulsory jurisdiction which would be competent to resolve norm-conflicts. Most of the international legal rules arise from the consent reached among its participants. If one takes consent as a determining factor, one can easily accept that UNGPs, which are adopted unanimously, include binding obligations.

The UNGPs are an example of a formally soft law UN document that has through wide-spread, general and systematic practice of states, international organisations, businesses and domestic and regional judicial institutions acquired the status of authoritative document that reflects binding obligations of states. Surely, they are not formal sources of international law. However, those stakeholders have agreed that the content of the UNGPs arises to at least substantive legality if formal legality was not possible due to their legal form. Therefore, UNGPs should be considered as a material source of international law. Accordingly, the UNGPs have been over past decades domesticated by domestic and international legal systems thereby raising to the status of material sources of international law. All in all, participants in domestic and international environments have in the past decades recognized that the UNGPs on Business and $\mathrm{Hu}-$ man Rights are not only soft law international document, but a material source of state obligations in business and human rights. The ability and capacity of international institutional actors therefore should not be underestimated. The example of the UNGPs illustrates that they under certain conditions contribute to international law-making.

\section{BIBLIOGRAPHY}

1. Aaronson, S. A., Higham I., 2013, "Re-righting Business": John Ruggie and the Struggle to Develop International Human Rights Standards for Transnational Firms' Human Rights Quarterly, 35.

2. Addo, M., 2014, The Reality of the United Nations Guiding Principles on Business and Human Rights, Human Rights Law Review, Vol. 14.

64 Augenstein, D., 2012, The Crisis of International Human Rights Law in the Global Market Economy, Netherlands Yearbook of International Law, 44, p. 41. 
3. Aspremont, J. d', 2011, Formalism and the Sources of International Law. A Theory of the Ascertainment of Legal Rules, Oxford, Oxford University Press.

4. Augenstein, D., 2012, The Crisis of International Human Rights Law in the Global Market Economy, Netherlands Yearbook of International Law, 44.

5. Besson, S., Aspremont, J. d', The Sources of International Law: An Introduction, in: Besson, S., Aspremont, J. d' (eds.), 2014, The Oxford Handbook of the Sources of International Law, Oxford University Press.

6. Blackwell, S., Vander Meulen, N., 2016, Two Roads Converged: The Mutual Complementarity of a Binding Business and Human Rights Treaty and National Action Plans on Business and Human Rights, Notre Dame Journal of International and Comparative Law, 6.

7. Carrillo Santarelli, N., 2013, Necessity and Possibilities of the International Protection of Human Dignity from Non-State Violations, PhD Thesis, Universidad Autónoma de Madrid.

8. Clapham, A., 2006, Human Rights Obligations of Non-State Actors, Oxford, Oxford University Press.

9. Catá Backer, L., 2012, From Institutional Misalignments to Socially Sustainable Governance: The Guiding Principles for the Implementation of the United Nations Protect, Respect and Remedy and the Construction of Inter-Systemic Global Governance, Pacific McGeorge Global Business \& Development Law Journal, Vol. 25, Issue 1.

10. Catá Backer, L., 2015, Moving Forward the UN Guiding Principles for Business and Human Rights: Between Enterprise Social Norm, State Domestic Legal Orders, and the Treaty Law That Might Bind Them All, Fordham International Law Journal, 38.

11. Chinkin, C., 2000, Normative Development in the International Legal System, in: Shelton, D., (ed.), Commitment and Compliance: The Role of Non-binding Norms in the International Legal System, Oxford, Oxford University Press.

12. Choudhury, B., Hardening Soft Law Initiatives in Business and Human Rights, in: Plessis, J. J. du, Keong Low, C. (eds.), 2017, Corporate Governance Codes for the $21^{\text {st }}$ Century, Cham, Switzerland, Springer.

13. Deva, S., 2012, Regulating Corporate Human Rights Violations: Humanizing Business, London, New York, Routledge.

14. Deva, S., Treating Human Rights Lightly: A Critique of the Consensus Rhetoric and the Language Employed by the Guiding Principles. In: Deva, S., Bilchitz, D. (eds.), 2013, Human Rights Obligations of Business: Beyond the Corporate Responsibility to Respect?, Cambridge, Cambridge University Press.

15. Deva, S., 2021, The UN Guiding Principles' Orbit and Other Regulatory Regimes in the Business and Human Rights Universe: Managing the Interface, Business and Human Rights Journal, Vol. 6, Issue 2.

16. Deva, S., Bilchitz, D. (eds.), 2013, Human Rights Obligations of Business: Beyond the Corporate Responsibility to Respect, Cambridge, Cambridge University Press.

17. Dupuy, P-M., 1991, Soft Law and the International Law of the Environment, Michigan Journal of International Law, 12. 
18. Felice, D. de, Graf, A., 2015. The Potential of National Action Plans to Implement Human Rights Norms: An Early Assessment with Respect to the UN Guiding Principles on Business and Human Rights, Journal of Human Rights Practice, 7.

19. Kinley, D., Nolan, J., Zerial, N., 2007, The Politics of Corporate Social Responsibility: Reflections on the United Nations Human Rights Norms for Corporations, Company and Securities Law Journal, Vol. 25, Issue 1.

20. Kinley, D., Tadaki, J., 2004, From Talk to Walk: The Emergence of Human Rights Responsibilities for Corporations at International Law, Virginia Journal of International Law, 44.

21. Haász, V., 2013, The Role of National Human Rights Institutions in the Implementation of the UN Guiding Principles, Human Rights Review, 14.

22. Jägers, N., 2011, UN Guiding Principles on Business and Human Rights: Making Headway Towards Real Corporate Accountability? Netherlands Quarterly of $\mathrm{Hu}$ man Rights, 29.

23. Jägers, N., 2002, Corporate Human Rights Obligations: In Search of Accountability, Antwerp, Intersentia.

24. Jovanović, M. A., 2019, The Nature of International Law, Cambridge, Cambridge University Press.

25. Lagoutte, S., The UN Guiding Principles on Business and Human Rights: A Confusing 'Smart Mix' of Soft and Hard International Human Rights Law, in: Lagoutte, S., Gammeltoft-Hansen, T., Cerone, J. (eds.), 2016, Tracing the Roles of Soft Law in Human Rights, Oxford, Oxford University Press.

26. Lavrysen, L., 2017, Human Rights in a Positive State, Rethinking the Relationship between Positive and Negative Obligations under the European Convention on $\mathrm{Hu}$ man Rights, Cambridge, Intersentia.

27. Letnar Černič, J., 2010, Human Rights Law and Business, Groningen, Europa Law Publishing.

28. Letnar Černič, J., 2020, Corporate Accountability under Socio-Economic Rights, (Transnational Law and Governance), Oxon, New York, Routledge.

29. Letnar Černič. J., Ho, T. van (eds.), 2015, Human Rights and Business: Direct Corporate Accountability for Human Rights, Wolf Publishing.

30. O’Brien, C., 2020, Transcending the Binary: Linking Hard and Soft Law Through a UNGPS-Based Framework Convention, AJIL Unbound, 114.

31. Márquez Carrasco, C., Vivas Tesón, I., (eds.), 2017, La implementación de los Principios Rectores de las Naciones Unidas sobre empresas y los derechos humanos por la Unión Europea y sus Estados miembros, Madrid, Aranzadi Thomson Reuters, Ministerio de Economía, Industria y Competitividad..

32. Martin Amerson, J., 2012, The End of the Beginning? A Comprehensive Look at the Business and Human Rights Agenda from a Bystander Perspective, Fordham Journal of Corporate and Finance Law, 17.

33. McCorquodale et al., 2017, Human Rights Due Diligence in Law and Practice: Good Practices and Challenges for Business Enterprises, Business and Human Rights Journal, Vol. 2, Issue 2.

34. Michalowski, S., 2012, No Complicity Liability for Funding Gross Human Rights Violations, Berkeley Journal of International Law, 30. 
35. Nolan, J., 2017, Business and Human Rights: The Challenge of Putting Principles into Practice and Regulating Global Supply Chains, Alternative Law Journal, Vol. 42, Issue 1.

36. Pauwelyn, J., Wessel, R. A., Wouters, J. (eds.), 2012, Informal International Lawmaking, Oxford, Oxford University Press.

37. Ramasastry, R., 2015, Corporate Social Responsibility Versus Business and Human Rights: Bridging the Gap Between Responsibility and Accountability, Journal of Human Rights, 14.

38. Ramio Marles, C., Alsina Burgues, V., 2016, The Role of the Ombudsman in Protecting the Rights of Consumers of Services of General Interest Provided by Private Companies, US-China Law Review, 13.

39. Regulation (EU) 2017/821 of the European Parliament and of the Council of 17 May 2017 laying down supply chain due diligence obligations for Union importers of tin, tantalum and tungsten, their ores, and gold originating from conflict-affected and high-risk areas, OJ L 130, 19. 5. 2017.

40. Ruggie, J. G., 2004, Business and Human Rights: The Evolving Agenda, American Journal of International Law, 101.

41. Ruggie, J., 2008, Protect, Respect and Remedy: A Framework for Business and Human Rights: Report of the Special Representative of the Secretary-General on the Issue of Human Rights and Transnational Corporations and Other Business Enterprises, John Ruggie, A/HRC/8/5.

42. Ruggie, J. G., 2013, Just Business: Multinational Corporations and Human Rights, New York, W. W. Norton \& Co.

43. Ruggie, J. G., 2014, Global Governance and "New Governance Theory": Lessons from Business and Human Rights, Global Governance, Vol. 20, Issue 1.

44. Ruggie, J., Rees, C., Davis, R., 2021, Years After: From UN Guiding Principles to Multi-Fiduciary Obligations, Business and Human Rights Journal, Vol. 6, Issue 2.

45. Sanders, A., The Impact of the "Ruggie Framework" and the United Nations Guiding Principles on Business and Human Rights on Transnational Human Rights Litigation, in: Martin, J., Bravo, K. (eds.), 2016, The Business and Human Rights Landscape: Moving Forward, Looking Back, Cambridge, Cambridge University Press.

46. Schutter, O. de, Foreword: Beyond the Guiding Principles, in: Deva, S., Bilchitz, D. (eds.), 2013, Human Rights Obligations of Business: Beyond the Corporate Responsibility to Respect? Cambridge, Cambridge University Press.

47. Schutter, O. de et al., 2012, Commentary to the Maastricht principles on extraterritorial obligations of states in the area of economic, social and cultural rights, Human Rights Quarterly, Vol. 34, Issue 4.

48. Vasquez, C. M., 2005, Direct vs. Indirect Obligations of Corporations under International Law, Columbia Journal of Transnational Law, 43.

49. Weissbrodt, D., Kruger, M., 2003, Norms on the Responsibilities of Transnational Corporations and Other Business Enterprises with Regard to Human Rights, American Journal of International Law, 97. 
50. Wettstein, F., The History of "Business and Human Rights" and Its Relationship with Corporate Social Responsibility, in: Deva. S., Birchall, D., (eds.), 2020, Research Handbook on Human Rights and Business, Cheltenham, Edward Elgar.

51. Wettstein, F., 2021, Betting on the Wrong (Trojan) Horse: CSR and the Implementation of the UN Guiding Principles on Business and Human Rights, Business and Human Rights Journal, Vol. 6, Issue 2.

\section{LEgAL ACTS}

1. California Transparency in Supply Chains Act, CAL. CIV. CODE $§ 1714.43$ (West, 2010).

2. Directive 2014/95/EU of the European Parliament and of the Council of 22 October 2014 amending Directive 2013/34/EU as regards disclosure of non-financial and diversity information by certain large undertakings and groups. Text with EEA relevance.

3. Elements for the Draft Legally Binding Instrument on Transnational Corporations and Other Business Enterprises with Respect to Human Rights, Chairmanship of the OEIGWG established by HRC Res. A/HRC/RES/26/9, 29 September 2017.

4. Loi 2017-399 du 27 Mars 2017 relative au devoir de vigilance des sociétés mères et des entreprises donneuses d'ordre, Official Gazette of the Republic of France, 27 March 2017.

5. Maastricht principles on extraterritorial obligations of states in the area of economic, social and cultural rights, 21 October 2011.

6. Modern Slavery Act (UK, 2015).

7. Modern Slavery Act 2018, Australia (No. 153, 2018).

8. Norms on the Responsibilities of Transnational Corporations and Other Business Enterprises with Regard to Human Rights, UN doc. E/CN.4/Sub.2/2003/12/Rev. 2 (2003).

9. The Dutch Child Labour Due Diligence Law, Eerste Kamer, vergaderjaar 20162017, 34 506, A.

10. United Nations High Commissioner for Human Rights, Report on "Improving accountability and access to remedy for victims of business-related human rights abuse, United Nations General Assembly, A/HRC/32/19, 10 May 2016.

11. United Nations Committee on Economic, Social and Cultural Rights, General Comment No. 24 on State obligations under the International Covenant on Economic, Social and Cultural Rights in the context of business activities, E/C.12/ GC/24, 10 August 2017.

\section{Case LaW}

1. Connelly v. R.T.Z. Corporation, [1998] A.C. 854 at 868-69.

2. Connelly v. R.T.Z. Corp. Plc., [1998] A.C. 854 (House of Lords) (citing Sim v. Robinow, 1892 Sess. Cas. (R.) 668.

3. Spiliada Maritime Corp. v. Cansulex Ltd., [1987] A.C. 460, 474. 


\section{INTERNET SOURCES}

1. Bauer, J., What Good is a NAP for Developing Countries? A Preliminary Assessment of Achievements and Prospects for National Action Plans on Business and Human Rights in the Global South, SSRN, (https://ssrn.com/abstract=3221052).

2. García Muñoz, S., 2019, Special Rapporteur on Economic, Social, Cultural and Environmental Rights, Business and Human Rights: Inter-American Standards, IDH, (http://www.oas.org/en/iachr/reports/pdfs/Business_Human_Rights_Inte_American_Standards.pdf).

3. Gesetz über die unternehmerischen Sorgfaltspflichten in Lieferketten. Bundesgesetzblatt Jahrgang 2021, Nr. 46, 22. 7. 2021, 2959, (https://www.bgbl.de/xaver/ bgbl/start.xav?startbk=Bundesanzeiger_BGBl\#__bgbl_o2F\%2F*\%5B\%40attr_ id\%3D\%27bgbl121s2959.pdf\%27\%5D_1627115664209, 15. 11. 2021).

4. Hamm, B., 2021, The Struggle for Legitimacy in Business and Human Rights Regulation-a Consideration of the Processes Leading to the UN Guiding Principles and an International Treaty, Humam Rights Review, (https://doi.org/10.1007/ s12142-020-00612-y).

5. Lappin, K., Pedersen, H., Khan, T., 2016, Influence of corporations in treaty process would undermine affected communities' interests, Business \& Human Rights Resource Centre, March 28, (http://business-humanrights.org/en/influence-of-corporations-in-treaty-process-would-undermine-affected-communities\%E2\%80\%99-interests, 20. 11. 2021).

6. Lopes, R., Kwesiga, A., 2018, What the Zero Draft and Protocol Lack: Meaningful Access to Justice - a Global South Perspective, Business and Human Rights Resource Centre, 8 October, (https://www.business-humanrights.org/en/blog/whatthe-zero-draft-and-protocol-lack-meaningful-access-to-justice-a-global-southperspective/ 20. 11.2021).

7. Lorenzo, F. di, Levin-Nally, E., 2021, The "Conflict Minerals Regulation" or the "Regulation on Responsible Sourcing of Minerals": Evolving Purpose and Terminology, Business and Human Rights Journal Blog, 22 February, (https://www.cambridge.org/core/blog/2021/02/22/the-conflict-minerals-regulation-or-the-regulation-on-responsible-sourcing-of-minerals-evolving-purpose-and-terminology/ 10. 11. 2021).

8. Sorgfaltsprüfung bezüglich Menschenrechte und Umwelt im Zusammenhang mit Auslandaktivitäten von Unternehmen: Kein Schweizer Alleingang in der Gesetzgebung (2019). Bern. URL: (https://static.woz.ch/sites/woz.ch/files/text/download/lobbyschreiben von_8august2019.pdf, 15. 11. 2021).

9. Treaty Alliance, We call on states to participate actively in upcoming negotiations of the international treaty to ensure protection of human rights from the activities of transnational corporations and other business enterprises, 29 May 2015, (https://www.business-humanrights.org/en/treaty-alliance-joint-statementcalls-for-signatures-in-favour-of-proposed-binding-treaty-to-enhance-corporatelegal-accountability-for-rights-abuses, 10. 11. 2021).

10. UN Human Rights Council Resolution A/HRC/RES/26/9, 14 July 2014, (https:// undocs.org/A/HRC/RES/26/9, 20. 11. 2021). 
11. UN Working Group on the issue of human rights and transnational corporations and other business enterprises, State National Action Plans, (https://www.ohchr. org/EN/Issues/Business/Pages/NationalActionPlans.aspx, 20. 11. 2021).

12. Vedanta Resources PLC and another v. Lungowe and others; [2019] UKSC 20. Judgment, (https://www.supremecourt.uk/cases/docs/uksc-2017-0185-judgment. pdf, 10. 11. 2021), UK Supreme Court, 10 April 2019.

13. Yilmaz-Vastardis, A., Leader, S., 2017, Improving Paths to Business Accountability for Human Rights Abuses in the Global Supply Chains, Essex Business and Human Rights Project, (https:// www1.essex.ac.uk/ebhr/documents/Improving-Paths-to-Accountability-for-Human\%20Rights-Abuses-in-the-Global-Supply-chains-A-LegalGuide.pdf, 10. 11. 2021).

\title{
INSTITUCIONALNI AKTERI KAO MEĐUNARODNI ZAKONODAVCI U OBLASTI BIZNISA I LJUDSKIH PRAVA: RUKOVODEĆA NAČELA UJEDINJENIH NACIJA O BIZNISU I LJUDSKIM PRAVIMA I ŠIRE
}

\author{
Jernej Letnar Černič
}

\begin{abstract}
APSTRAKT
Biznis i ljudska prava predstavljaju interdisciplinarnu oblast, koja se zalaže za to da i država i poslovni subjekti budu nosioci obaveza koje se tiču ljudskih prava. Oblast biznisa i ljudskih prava ima za cilj da reguliše i spreči negativne uticaje poslovanja na svim nivoima globalnih lanaca snabdevanja. Pristup međunarodnog prava u ovom pogledu je do sada bio ograničen. Države su tradicionalno bile glavni učesnik u međunarodnoj zajednici. Ipak, ovaj članak ima za cilj da testira argumente koje je Jovanović izneo u svojoj knjizi Priroda međunarodnog prava iz 2019. godine, a to je da su institucionalni nedržavni akteri sposobni da kreiraju pravila međunarodnog prava. Opremljen ovim saznanjima, ovaj članak tvrdi da je Savet UN za ljudska prava usvajanjem Rukovodećih načela o biznisu i ljudskim pravima ponovio obaveze država i indirektno korporacija u pogledu ljudskih prava u međunarodnom pravu kako bi zaštitio dostojanstvo nosilaca prava u lokalnom i globalnom okruženju.

Ključne reči: filozofija međunarodnog prava, institucionalni akteri, biznis i ljudska prava, ljudska prava, državne obaveze, korporativne obaveze, Rukovodeća načela Ujedinjenih nacija o biznisu i ljudskim pravima.
\end{abstract}

Article History:

Received: 22 November 2021

Accepted: 6 December 2021 